\title{
Effect of Pomegranate Juice on the Manufacturing Process and Characterization of Feta-Type Cheese during Storage
}

\author{
Hannan Lashkari $\mathbb{D}^{1,2}$ Mohammad Javad Varidi, ${ }^{2}$ Mohammad Hadi Eskandari, ${ }^{3}$ \\ and Mehdi Varidi ${ }^{2}$ \\ ${ }^{1}$ Department of Food Science and Technology, Zarindasht Branch, Islamic Azad University, Zarindasht, Iran \\ ${ }^{2}$ Department of Food Science and Technology, College of Agriculture, Ferdowsi University of Mashhad, Mashhad, Iran \\ ${ }^{3}$ Department of Food Science and Technology, College of Agriculture, Shiraz University, Shiraz, Iran
}

Correspondence should be addressed to Hannan Lashkari; hlashkari@gmail.com

Received 2 August 2020; Revised 5 November 2020; Accepted 7 November 2020; Published 29 November 2020

Academic Editor: Chunpeng Wan

Copyright (c) 2020 Hannan Lashkari et al. This is an open access article distributed under the Creative Commons Attribution License, which permits unrestricted use, distribution, and reproduction in any medium, provided the original work is properly cited.

\begin{abstract}
The present research aimed to produce Fruit Feta-type cheese and investigate the effects of pomegranate juice on the manufacturing process and characterization of Feta-type cheese during storage. In order to produce Feta-type cheese with pomegranate juice, part of the milk was replaced with pomegranate juice. Therefore, it was necessary to produce Feta-type cheese with whey-less method, which is a good substitute for ultrafiltrated cheese. Initially, whey-less Feta-type cheese was produced. The formula was optimized based on the physicochemical characteristics of the marketed ultrafiltrated Feta cheeses. At the optimal point, the amount of cream, MPC, WPC, and fresh milk were 45.6, 11.7, 2.7, and 40\%, respectively. Whey-less Feta-type cheese with these ratios was produced and the effects of different levels of pomegranate juice $(0,5,10,15$, and $20 \%)$ on its physicochemical, textural, microbial, and sensorial properties during 60 days of storage were studied. The results showed that pomegranate juice increased acidity, total phenol, anthocyanin, DPPH inhibition, and $\mathrm{a}^{*}$ value, and reduced the $\mathrm{pH}$, peroxide value, thiobarbituric acid (TBA), proteolysis, lipolysis, and $\mathrm{L}^{*}$ and $\mathrm{b}^{*}$ values. Adding pomegranate juice to cheese reduced all of the textural indices except the adhesiveness. Sensory evaluation of the samples showed that the sample containing $20 \%$ of pomegranate juice had a higher score and was selected as the best sample.
\end{abstract}

\section{Introduction}

Cheese is one of the most consumed dairy products in most parts of the world. The diversity and the high nutritional value of cheese have given a special position for it in the diet of many countries. Feta is a semi-soft, white brined, protected designation of origin traditional Greek cheese, made from ovine milk or mixtures of it with caprine milk (up to $30 \%$ ) [1]. Traditionally, Feta cheese is made from raw milk in small family premises with elementary equipment. Sometimes, the producers apply a milder than high-temperature short-time (HTST) heat treatment of milk and traditional yogurt used as a starter [2].Therefore, in order to increase the per capita consumption of cheese, new types of cheese with good nutritional and sensory properties should be produced.
In recent years, different types of fruit-flavored dairy products have been produced and marketed. However, there has been no specific study on the production of cheese containing fruit juice. In addition to the functional properties, this product can be accepted by consumers in terms of sensory and nutritional features. Dairy products, such as cheese, are able to carry functional compounds and release them in the body due to the ability to form a gel [3]. Adding these compounds to cheese can improve its antioxidant activity, functional properties, color, and nutritional value. There is some research regarding production of fruit cheese such as guava-based papaya fruit cheese [4], Gouda cheese supplemented with fruit liquors [5], functional cheese from goat milk supplemented with baobab fruit pulp [6], and guava cheese fortified with perishable loss of fruits [7]. 
Among fruits, pomegranate is rich in phenolic compounds and has antioxidant capacity and the potential to inhibit free radicals [8]. Pomegranate (Punica granatum L.) belongs to the Punicaceae family and is native from Iran to northern India. Numerous researches have shown that bioactive compounds in pomegranate juice are useful for lowering blood pressure, reducing blood cholesterol, preventing cardiovascular diseases, blocking blood vessels, and preventing a variety of cancers. The total pomegranate production in the world was estimated to be around 3 million tons in 2014 and 3.8 million tons in 2017. Due to the rapid increase in the production, it is highly difficult to calculate the total production [9]. Zarban et al. [8] studied the antioxidant activity and the ability to neutralize free radicals of nine commercial fruit juices, and observed that pomegranate juice had the highest phenolic compounds and total antioxidant activity. Han et al. [10] developed a functional cheese containing phenolic compounds and investigated the antioxidant properties of the samples. They used single-ring phenolic compounds, including catechin, tannic acid, and flavones, and natural compounds, such as grape extract, green tea extract, and corn powder, as functional compounds in the preparation of cheese. Cheese matrix containing $0.5 \mathrm{mg} / \mathrm{mL}$ polyphenolic compounds exhibited a significant effect in the absorption of free radicals.

In order to produce Feta-type cheese with pomegranate juice, it is necessary to replace part of the milk with pomegranate juice. The $\mathrm{pH}$ of pomegranate juice is low and it cannot be added directly to milk; therefore, milk protein powder should be added to fresh milk first and then pomegranate juice should be added. Milk proteins have buffering properties [11]. Hence, it is necessary to produce Feta-type cheese with whey-less method, which is a good substitute for ultrafiltrated cheeses [12]. Whey produced from cheese making, as a by-product, limits productivity. The production of whey can create additional costs for waste treatment, even though whey contains food-grade ingredients that have been separated from milk. In the production of cheese in the whey-less method, different proportions of milk protein concentrate, whey protein concentrate, sodium caseinate, whole milk powder, skimmed milk powder, fat replacers, cream, vegetable fat, and fresh milk are used, and the cheese is similar to ultrafiltrated cheese [12]. The objective of this study was to optimize the formulation of wheyless Feta-type cheese using milk protein concentrate, whey protein concentrate, and cream, and evaluate the effects of pomegranate juice on the characterization of whey-less Fetatype cheese.

\section{Materials and Methods}

\subsection{Whey-Less Feta-Type Cheese Production}

2.1.1. Raw Materials. Fresh milk was obtained from Holstein dairy cows on local farms in Shiraz. Cream and milk protein concentrate (MPC) were obtained from Fars Pegah Dairy Co. (Shiraz, Iran) and whey protein concentrate (WPC) was purchased From Glanbia Co. (Germany).
Chymosin (Clerici Sacco International-Caglificio Clerici $\mathrm{SpA}$, Italy) and culture (FEM Feferm, Optiferm $\mathrm{GmbH}$, Germany) were used as rennet and starter, respectively.

2.1.2. Experimental Design. In the current investigation, the effects of MPC (5-15\%), WPC (0-10\%), and cream $(45-55 \%)$ on the properties of whey-less cheese were evaluated by Simplex-Lattice mixture design. This experimental design was carried out in the form of 14 treatments. The levels of raw material for treatments are given in Table 1.

2.1.3. Cheese Processing. MPC and WPC powders and cream were added to fresh milk according to the experimental design. The mixtures were heated at $45^{\circ} \mathrm{C}$ for $1 \mathrm{~h}$ to hydrate the powders and homogenized at 50 bar through a singlestage valve homogenizer and pasteurized at $63^{\circ} \mathrm{C}$ for $30 \mathrm{~min}$. After cooling to $35^{\circ} \mathrm{C}$, they were transferred to cheese vats, and starter culture was added at a level of 10 units/1000 L and $\mathrm{CaCl}_{2}$ at a level of $0.2 \mathrm{~g} \cdot \mathrm{L}^{-1}$ milk. The inoculated milk was held for $30 \mathrm{~min}$ at $35^{\circ} \mathrm{C}$ and salt $(15 \mathrm{~g} / 1000 \mathrm{~L}$ directly before the formation of the clot) and rennet $(0.04 \mathrm{~g} / 1000 \mathrm{~L})$ were added to the milk. The mixtures were transferred to $100 \mathrm{~g}$ plastic containers and kept for $20 \mathrm{~min}$ at $35^{\circ} \mathrm{C}$ to form a coagulum. Finally, containers were heat sealed with aluminum coat. The cheese samples were incubated at $40^{\circ} \mathrm{C}$ for $4 \mathrm{~h}$ and then refrigerated at $6^{\circ} \mathrm{C}$. After 48 hours, samples were subjected to different tests [13].

\subsubsection{Optimization of Whey-Less Feta-Type Cheese} Formulation. The samples of Whey-less Feta-type cheese were subjected to different tests. The optimization was carried out by desirability function and averages of the properties of market cheeses. Seven different brands of ultrafiltrated Feta-type cheese marketed in Iran were selected and their physicochemical and texture indices were measured in three replicates. Numerical optimization was performed with Design Expert ${ }^{\circledR 9} 9.0$ software and optimized percentages of raw materials were obtained.

\subsection{Fruit Whey-Less Feta-Type Cheese Production}

2.2.1. Pomegranate Juice Preparation. Pomegranate fruit cv. "Rabbab-e- Shiraz" was harvested from Qasro-Dasht Gardens of Shiraz. After washing the fruit and the manual granulation, the pomegranate juice was obtained by pressing the seeds and then filtering and pasteurizing $\left(70^{\circ} \mathrm{C}\right.$ for $10 \mathrm{~min})$. Pomegranate juices were stored at $-20^{\circ} \mathrm{C}$.

2.2.2. Cheese Processing. To produce fruit Feta cheese, the optimal ratios of fresh milk, cream, MPC, and WPC powders were mixed together. According to the method of whey-less Feta-type cheese production, the mixture was homogenized, pasteurized, and cooled. Pomegranate juice was added to milk at $35^{\circ} \mathrm{C}$. Then the culture, salt, $\mathrm{CaCl}_{2}$, and rennet were added according to the whey-less Feta-type cheese production method. This mixture was transferred to $100 \mathrm{~g}$ 
TABLE 1: Experimental design variables* and levels**.

\begin{tabular}{lccc}
\hline Run & WPC (\%) & MPC (\%) & Cream (\%) \\
\hline 1 & 3.33 & 8.33 & 48.3 \\
2 & 6.67 & 6.67 & 46.7 \\
3 & 0.00 & 10.0 & 50.0 \\
4 & 0.00 & 5.00 & 55.0 \\
5 & 5.00 & 5.00 & 50.0 \\
6 & 5.00 & 10.0 & 45.0 \\
7 & 0.00 & 15.0 & 45.0 \\
8 & 10.0 & 5.00 & 45.0 \\
9 & 1.67 & 11.67 & 46.7 \\
10 & 0.00 & 15.0 & 45.0 \\
11 & 10.0 & 5.00 & 45.0 \\
12 & 0.00 & 10.0 & 50.0 \\
13 & 0.00 & 5.00 & 55.0 \\
14 & 1.67 & 6.67 & 51.7 \\
\hline
\end{tabular}

*WPC: whey protein concentrate; MPC: milk protein concentrate. ${ }^{* *} \mathrm{~g} / 100 \mathrm{~g}$ of cheese.

plastic containers and kept for $20 \mathrm{~min}$ at $35^{\circ} \mathrm{C}$ to form a coagulum and finally heat sealed with an aluminum coat. The cheeses were incubated at $40^{\circ} \mathrm{C}$ until their $\mathrm{pH}$ reached 4.8 and then placed in a refrigerator at $6^{\circ} \mathrm{C}$ for 60 days. Samples were evaluated using physicochemical, sensory, and microbial tests at 15 day intervals.

2.3. Physicochemical Analysis. Total solids, titratable acidity based on lactic acid (w/w), protein, ash, salt, and $\mathrm{pH}$ of samples were measured according AOAC [14]. Syneresis was measured by determining the weight ratio of whey to curd during the time of storage [15]. The surface color of the samples was determined by a digital Canon camera (Canon, Model IXUS 230 HS, 14.0 Megapixels, Tokyo, Japan). The resultant pictures were studied by Adobe Photoshop CS 6 Software and the main color parameters, such as $\mathrm{L}^{*}, \mathrm{a}^{*}$ and $\mathrm{b}^{*}$, were extracted. [16]. To evaluate the degree of proteolysis, nonprotein nitrogen index (NPN) was determined [17]. Lipolysis was evaluated by determining the acidity index. Fat was extracted from cheese samples using diethyl ether and their acidity values (mill equivalent per 100 grams of fat) were determined by titration with alcoholic potash [17]. To determine the thiobarbituric acid and the peroxide value, the fat was extracted using chloroform [18]. Thiobarbituric acid's value as a secondary oxidation product and peroxide value were determined based on the Kirk and Sawyer [19] method. To measure the total phenolic content and the total anthocyanin content and determine the antioxidant capacity of cheese samples, an aliquot of cheese $(5 \mathrm{~g})$ was mixed with methanol $(40 \mathrm{ml})$ and placed on a shaker for $1 \mathrm{~h}$ at $65^{\circ} \mathrm{C}$ and then centrifuged for 15 minutes at $4^{\circ} \mathrm{C}$. Supernatant was used as a cheese extract in antioxidant tests. The amount of total phenolic compounds present in the samples was investigated using the "Folin-Ciocalteu" method [20]. The total amount of anthocyanins was measured using the colorimetric method (absorbance difference at different $\mathrm{pHs}$ ) [21]. To measure the antioxidant activity, DPPH solution at a concentration of $0.1 \mathrm{mM}$ in methanol was used and the absorbance was read at $517 \mathrm{~nm}[20]$.

2.4. Texture Analysis. The textural properties were evaluated by a texture analyzer (CT3 Brookfield, USA). For this purpose, cheese samples were placed at room temperature for $10 \mathrm{~min}$. Then, cylindrical specimens with a $27 \mathrm{~mm}$ diameter and $20 \mathrm{~mm}$ height were taken from cheese samples and placed in the texture analyzer and compressed by a probe with $35 \mathrm{~mm}$ diameter to $20 \%$ of their original height. The speed of the probe was $60 \mathrm{~mm} / \mathrm{min}$. Hardness, cohesiveness, adhesiveness, gumminess, chewiness, and springiness were determined from the curve [22].

2.5. Microbiological Analysis. Total counts were evaluated by plate count agar at $37^{\circ} \mathrm{C}$ for $48 \mathrm{~h}$. The mesophilic and thermophilic lactobacilli were determined by MRS agar at $30^{\circ} \mathrm{C}$ and $45^{\circ} \mathrm{C}$, respectively, for $48 \mathrm{~h}$. Also, the mesophilic and thermophilic lactococci were enumerated by M17 agar at $30^{\circ} \mathrm{C}$ and $37^{\circ} \mathrm{C}$, respectively, for $48 \mathrm{~h} \mathrm{[23].}$

2.6. Sensory Analysis. Sensory evaluation of samples was performed after 30 days. Samples were randomly coded and placed for 30 minutes at room temperature and then evaluated by a group of 20 trained panelists. Surface color, internal color, surface appearance, internal appearance, flavor, texture, and general acceptance were evaluated by the 5-point hedonic method (minimum and maximum satisfaction were rated 1 to 5 , respectively) [12].

\subsection{Statistical Analysis}

2.7.1. Whey-Less Feta-Type Cheese Production. Design Expert ${ }^{\circledR 9} 9.0$ software was used to determine experimental design and analyze the data. Mixture design is defined as a spatial type of RSM in which the factors are the components of a mixture and the response varies as the proportions vary, i.e., the response is affected by the variation of the proportions. One of the most widely used mixture design types is the Simplex-Lattice design [24]. For each response, analysis of variance was conducted to determine significant differences among various treatments. The relationship between each of the responses with independent variables was modeled. In order to evaluate the validity of the fitted models, the values of adj- $\mathrm{R}^{2}$ coefficients and lack of fit test were determined. Finally, optimization of whey-less Fetatype cheese, based on the physicochemical and textural properties of market cheeses, was done.

2.7.2. Fruit Whey-Less Feta-Type Cheese Production. The effects of pomegranate juice concentration on properties of whey-less Feta-type cheese were evaluated by a completely randomized design with at least 3 replications. SPSS V. 25 statistical software was used for ANOVA analysis of the results and Duncan post hoc test for multiple comparisons were done at a significant level of $0.05(p<0.05)$. 


\section{Results and Discussion}

3.1. Whey-Less Feta-Type Cheeses' Properties. With the aid of data analysis regression analysis by using Design Expert ${ }^{\circledR 9} 9$ software, the properties of all cheeses were modeled in the form of a polynomial equation as a function of independent variables. Using ANOVA, the significance of the linear and interaction effects of regression model coefficients was investigated for each property. For evaluation of the validity of the fitted models, the values of adj- $\mathrm{R}^{2}$ coefficients and lack of fit test were used. As shown in Table 2, adj- $R^{2}$ of the models for various responses ranged from 0.87 to 0.99 , and they can be used to predict changes in these properties. The results showed that lack of fit for all properties measured at $95 \%$ confidence level was not significant. Therefore, the high adj$R^{2}$ coefficient and not significant lack of fit for all properties confirm the accuracy of the model for fit information. The numerical value of the properties of cheese can be predicted by substituting different percentages of cream, WPC, and $\mathrm{MPC}$ in the equations.

\subsection{Optimization of Whey-Less Feta-Type Cheeses (Numerical} Optimization). One of the most popular and the most frequently used approaches to simultaneous optimization is the desirability function approach. Individual goals are combined into a single objective measure to be maximized using a geometric mean function. It is possible to obtain an overall desirability from the individual desirabilities [24]. The numerical value of desirability is between zero and one and its low level indicates that the target is not reachable, while its high level indicates that the target is fully met. When the goal is to optimize multiple responses simultaneously, the desirability of each of the responses is determined and their geometric mean is used as an indicator of the simultaneous fulfillment of the goals. Based on the physicochemical properties of market cheeses (Table 3), numerical optimization was performed. The optimal point with the highest desirability was obtained with percentage of independent variables of cream, MPC, and WPC at 45.6, 11.7 , and $2.7 \%$, respectively. The characteristics of the cheese at the optimum point were listed in Table 3.

3.3. Properties of Pomegranate Juice. The chemical properties of pasteurized pomegranate juice are shown in Table 4. The results of pomegranate juice analysis showed that total soluble solids, acidity, total ash, and $\mathrm{pH}$ were $18.12,1.5$, $0.29 \%$, and 3.2, respectively. Akbarpour et al. [25] reported that total soluble solid, acidity, and $\mathrm{pH}$ of pomegranate juice obtained from Rabbab cultivar were 19.88\%, 1.49\%, and 3.09 respectively. Total phenol has been reported for Iranian pomegranate juices at $2960-9850 \mathrm{mg} / \mathrm{L}$, for Turkish commercial pomegranate juices at $1080-9449 \mathrm{mg} / \mathrm{L}$, and for Italian pomegranate juices at $1600-3730 \mathrm{mg} / \mathrm{L}$ [26]. The total phenol of pomegranate juice $(2450 \mathrm{mg} / \mathrm{L})$ in our study is within the range reported by previous researchers. The anthocyanin content of pomegranate juice was $270.82 \mathrm{mg} / \mathrm{L}$ in our study, while it was reported to be $81-369 \mathrm{mg} / \mathrm{L}$ in Turkish pomegranate juices, $2380-9300 \mathrm{mg} / \mathrm{L}$ in Iranian pomegranate juices, and $11-178 \mathrm{mg} / \mathrm{L}$ in Tunisia pomegranate juices [26].

3.4. Fruit Whey-less Feta-type Cheese Properties. Various characteristics of Feta-type cheese containing different pomegranate juice concentrations were analyzed during the storage time (60 days) at intervals of 15 days. The data were analyzed by SPSS software and the meanings were compared with Duncan's multiple range test. The results of the analysis showed that pomegranate juice has a very significant effect on all cheese properties $(p<0.0001)$. The pictures of Fetatype cheese containing different pomegranate juice concentrations on the first day after production are presented in Figure 1.

3.4.1. Physical and Chemical Properties. Physicochemical properties of cheese are shown in Table 5. The $\mathrm{pH}$ of cheese decreases as the amount of pomegranate juice increases. This is attributed to the presence of organic acids in pomegranate juice, such as citric acid and malic acid [27]. These results are consistent with the results of Salwa et al. [28]. With increasing percentage of pomegranate juice, the amount of whey increased. The syneresis process depends on the extensive redistribution of the casein network, after the formation of the initial gel. Redistribution is more intense at a higher temperature and lower $\mathrm{pH}$ [29]. During the time of storage, whey percentage was initially increased to the thirtieth day and then it showed a decreasing trend. Syneresis in the first weeks of storage is due to an increase in acidity and a decrease in $\mathrm{pH}$, as well as increased casein cross-linking and excessive contraction of the crude due to cooling. After 30 days, the whey is again absorbed into the crude; this appears to be due to increased proteolysis, followed by an increase in lyophilic insides in matrix of cheese then water absorption increased [29].

The results showed that pomegranate juice reduced the dry matter of the cheese (Table 5). This decrease could be due to the high humidity of pomegranate juice; therefore, as the percentage of pomegranate juice in the formulation increased, more water is absorbed by the WPC and MPC in the cheese matrix, which decreases the dry matter. Initially, until the 30th day, the amount of dry matter increased and then showed a decreasing trend. The whey diagram also confirms the changes in dry matter.

Pomegranate juice significantly reduced the amount of salt. With the constant initial amount of salt, with increasing pomegranate juice and the subsequent moisture content of cheese, its percentage decreased from 1.37 in the control to 1.12 in cheese with $20 \%$ pomegranate juice. Pomegranate juice significantly decreased the ash and protein content of cheese. This decrease is due to low percentage of ash and protein content of pomegranate juice compared to the control sample.

Pomegranate juice reduces nonprotein nitrogen. NPN is the index of proteolysis process. This process is the most important factor in curing the different types of cheese. The proteases of the starter are the most important proteolytic enzymes found in whey-less cheese. Due to the fact that all 
TABle 2: Predictive models for characteristics of whey-less Feta cheese.

\begin{tabular}{|c|c|c|}
\hline Responses & Predictive models & $R^{2}$ \\
\hline Syneresis (\%) & $0.574 \mathrm{~A}^{* * *}-2.550 \mathrm{~B}^{* * *}+17.484 \mathrm{C}^{* * *}+0.030 \mathrm{AB}^{\mathrm{ns}}-0.416 \mathrm{AC}^{* * *}-0.148 \mathrm{BC}^{* *}$ & 0.998 \\
\hline Dry matter $(\%)$ & $0.680 \mathrm{~A}^{* * *}-0.545 \mathrm{~B}^{* * *}+8.836 \mathrm{C}^{* * *}+0.025 \mathrm{AB}^{\mathrm{ns}}-0.183 \mathrm{AC}^{* * *}-0.054 \mathrm{BC}^{\mathrm{ns}}$ & 0.939 \\
\hline Fat $(\%)$ & $0.474 \mathrm{~A}^{* * *}-0.046 \mathrm{~B}^{* * *}+4.950 \mathrm{C}^{* * *}-0.0054 \mathrm{AB}^{\mathrm{ns}}-0.116 \mathrm{AC}^{* * *}-0.026 \mathrm{BC}^{\mathrm{ns}}$ & 0.991 \\
\hline Acidity (\% lactic acid) & $0.025 \mathrm{~A}^{* * *}-0.142 \mathrm{~B}^{* * *}+0.022 \mathrm{C}^{* * *}-0.0033 \mathrm{AB}^{*}-0.000028 \mathrm{AC}^{\mathrm{ns}}+0.00026 \mathrm{BC}^{\mathrm{ns}}$ & 0.946 \\
\hline Salt $(\%)$ & $0.018 \mathrm{~A}^{* * *}+0.096 \mathrm{~B}^{* * *}-0.124 \mathrm{C}^{* * *}-0.001 \mathrm{AB}^{\mathrm{ns}}+0.0037 \mathrm{AC}^{\mathrm{ns}}+0.0017 \mathrm{BC}^{\mathrm{ns}}$ & 0.939 \\
\hline Total protein $(\%)$ & $0.07 \mathrm{~A}^{* * *}-0.068 \mathrm{~B}^{* * *}+1.7 \mathrm{C}^{* * *}+0.018 \mathrm{AB}^{\mathrm{ns}}-0.031 \mathrm{AC}^{*}-0.018 \mathrm{BC}^{\mathrm{ns}}$ & 0.984 \\
\hline $\mathrm{pH}$ & $0.075 \mathrm{~A}^{* * *}+0.424 \mathrm{~B}^{* * *}+0.455 \mathrm{C}^{* * *}-0.0065 \mathrm{AB}^{\mathrm{ns}}-0.0067 \mathrm{AC}^{\mathrm{ns}}-0.0044 \mathrm{BC}^{\mathrm{ns}}$ & 0.945 \\
\hline Ash (\%) & $0.03 \mathrm{~A}^{* * *}-0.083 \mathrm{~B}^{* * *}-0.148 \mathrm{C}^{* * *}-0.0046 \mathrm{AB}^{\mathrm{ns}}+0.0064 \mathrm{AC}^{\mathrm{ns}}-0.0075 \mathrm{BC}^{*}$ & 0.920 \\
\hline Hardness (g) & $13.4 \mathrm{~A}^{* * *}+676.8 \mathrm{~B}^{* * *}+181.4 \mathrm{C}^{* * *}-14.0 \mathrm{AB}^{* * *}-5.57 \mathrm{AC}^{\mathrm{ns}}+0.28 \mathrm{BC}^{\mathrm{ns}}$ & 0.979 \\
\hline Cohesiveness & $0.0094 \mathrm{~A}^{* * *}+0.0036 \mathrm{~B}^{* * *}-0.025 \mathrm{C}^{* * *}$ & 0.867 \\
\hline Gumminess (g) & $6.47 \mathrm{~A}^{* * *}+304.9 \mathrm{~B}^{* * *}-80.5 \mathrm{C}^{* * *}-6.27 \mathrm{AB}^{*}+1.21 \mathrm{AC}^{\mathrm{ns}}-2.35 \mathrm{BC}^{\mathrm{ns}}$ & 0.942 \\
\hline Chewiness (mj) & $0.125 \mathrm{~A}^{* * *}+1.24 \mathrm{~B}^{* * *}+0.446 \mathrm{C}^{* * *}$ & 0.869 \\
\hline Springiness (mm) & $0.026 \mathrm{~A}^{* * *}+0.270 \mathrm{~B}^{* * *}-1.28 \mathrm{C}^{* * *}-0.00034 \mathrm{AB}^{\mathrm{ns}}+0.026 \mathrm{AC}^{\mathrm{ns}}+0.013 \mathrm{BC}^{\mathrm{ns}}$ & 0.923 \\
\hline Adhesiveness (mj) & $0.084 \mathrm{~A}^{* * *}+0.41 \mathrm{~B}^{* * *}-0.055 \mathrm{C}^{* * *}-0.014 \mathrm{AB}^{* *}-0.0031 \mathrm{AC}^{\mathrm{ns}}+0.014 \mathrm{BC}^{* *}$ & 0.988 \\
\hline Color- $\mathrm{L}^{*}$ & $1.035 \mathrm{~A}^{* * *}+2.89 \mathrm{~B}^{* * *}+0.718 \mathrm{C}^{* * *}-0.039 \mathrm{AB}^{* * *}+0.00075 \mathrm{AC}^{\mathrm{ns}}+0.040 \mathrm{BC}^{* * *}$ & 0.983 \\
\hline Color-a* & $0.072 \mathrm{~A}^{* * *}+0.18 \mathrm{~B}^{* * *}-0.214 \mathrm{C}^{* * *}-0.0066 \mathrm{AB}^{*}+0.0042 \mathrm{AC}^{\mathrm{ns}}+0.006 \mathrm{BC}^{\mathrm{ns}}$ & 0.984 \\
\hline Color-b* & $0.39 \mathrm{~A}^{* * *}+0.51 \mathrm{~B}^{* * *}+0.13 \mathrm{C}^{* * *}-0.012 \mathrm{AB}^{\mathrm{ns}}-0.00033 \mathrm{AC}^{\mathrm{ns}}+0.017 \mathrm{BC}^{\mathrm{ns}}$ & 0.979 \\
\hline Acceptance & $0.08 \mathrm{~A}^{* * *}+1.58 \mathrm{~B}^{* * *}+1.64 \mathrm{C}^{* * *}-0.034 \mathrm{AB}^{*}-0.040 \mathrm{AC}^{*}-0.02 \mathrm{BC}^{\mathrm{ns}}$ & 0.909 \\
\hline
\end{tabular}

A: cream\%, B: milk protein concentrate (MPC)\%, C: whey protein concentrate (WPC)\% ${ }^{* * *} p \leq 0.001,{ }^{* *} p \leq 0.01,{ }^{*} p<0.05$. ns, nonsignificant.

TABLE 3: Physicochemical characteristics of market Feta cheese and optimal cheese*

\begin{tabular}{|c|c|c|c|c|c|c|}
\hline Properties & Syneresis (\%) & Dry matter (\%) & Fat $(\%)$ & Acidity (\%) & Salt (\%) & Total protein $(\%)$ \\
\hline Market cheese & $0.21 \pm 12.20^{\mathrm{a}}$ & $37.10^{\mathrm{a}} \pm 0.56$ & $0.35 \pm 16.52^{\mathrm{a}}$ & $0.05 \pm 1.18^{\mathrm{a}}$ & $0.03 \pm 1.35^{\mathrm{a}}$ & $12.20^{\mathrm{a}} \pm 0.26$ \\
\hline Optimal cheese & $2.50^{\mathrm{b}} \pm 0.71$ & $37.40^{\mathrm{a}} \pm 0.57$ & $16.25^{\mathrm{a}} \pm 0.37$ & $0.01 \pm 1.09^{\mathrm{b}}$ & $1.38^{\mathrm{a}} \pm 0.03$ & $0.22 \pm 12.35^{\mathrm{a}}$ \\
\hline Properties & Ash (\%) & $\mathrm{pH}$ & Hardness (g) & Cohesiveness & Gumminess (g) & Chewiness (mj) \\
\hline Market cheese & $3.45^{\mathrm{a}} \pm 0.40$ & $5.10^{\mathrm{a}} \pm 0.12$ & $1161^{\mathrm{a}} \pm 50.00$ & $0.430^{\mathrm{b}} \pm 0.09$ & $552.00^{\mathrm{b}} \pm 33.6$ & $16.25^{\mathrm{b}} \pm 2.8$ \\
\hline Optimal cheese & $3.50^{\mathrm{a}} \pm 0.70$ & $0.07 \pm 4.75^{\mathrm{b}}$ & $1109^{\mathrm{a}} \pm 84.15$ & $0.565^{\mathrm{a}} \pm 0.17$ & $625.75^{\mathrm{a}} \pm 29.34$ & $21.09^{\mathrm{a}} \pm 1.64$ \\
\hline Properties & Springiness $(\mathrm{mm})$ & Adhesiveness (mj) & Color-L & Color-b & Color-a & \\
\hline Market cheese & $3.10^{\mathrm{a}} \pm 0.43$ & $2.3^{\mathrm{b}} \pm 0.22$ & $63.50^{\mathrm{a}} \pm 0.42$ & $17.00^{\mathrm{a}} \pm 0.64$ & $1.00^{\mathrm{b}} \pm 0.02$ & \\
\hline Optimal cheese & $3.44^{\mathrm{a}} \pm 0.50$ & $1.05^{\mathrm{a}} \pm 0.34$ & $62.70^{\mathrm{a}} \pm 0.424$ & $17.90^{\mathrm{a}} \pm 0.64$ & $2.40^{\mathrm{a}} \pm 0.15$ & \\
\hline
\end{tabular}

${ }^{*}$ Averages of three replicates have been reported as mean \pm standard deviation. Means within each column with different lowercase letters are significantly different $(p<0.05)$.

TABLE 4: Properties of pasteurized pomegranate juice*

\begin{tabular}{lccccc}
\hline Ash (\%) & Total soluble solids (\%) & Acidity (\%) & $\mathrm{pH}$ & Total phenol $(\mathrm{mg} / 100 \mathrm{ml})$ & Anthocyanin $(\mathrm{mg} / 100 \mathrm{ml})$ \\
\hline $0.29 \pm 0.05$ & $18.12 \pm 0.1$ & $0.02 \pm 1.5$ & $0.02 \pm 3.2$ & $12 \pm 245$ & $0.23 \pm 27.82$ \\
\hline
\end{tabular}

${ }^{*}$ Averages of three replicates have been reported as mean \pm standard deviation.

the added rennet remains in the whey-less cheese, rennet plays an important role in proteolysis and is responsible for the initial proteolysis of casein while the proteases of the initiating bacteria carry out further proteolysis and degrade the $\alpha s_{1}$. Hesari et al. [30] have confirmed the role of both factors in the proteolysis of Feta cheese. NPN decreases as the amount of pomegranate juice increases. Pomegranate juice also increases the moisture content of cheese, which in turn reduces the nonprotein nitrogen ratio.

3.4.2. Antioxidant Properties. Antioxidant properties of cheese are shown in Table 5 . The pomegranate antioxidant activity is mostly due to the presence of ascorbic acid and phenolic compounds such as ponicagelin, ponicaline, gallic acid, ethanolic acid, and anthocyanins [31]. Polyphenolic compounds of pomegranate can eliminate and neutralize free radicals 3-15 times more than other antioxidants, such as vitamins $\mathrm{C}$ and $\mathrm{E}$ [8] The pomegranate juice analysis showed that it contains $245 \pm 12(\mathrm{mg} / 100 \mathrm{~mL})$ of phenolic compounds. Zarban et al. [8] found that pomegranate juice contained $205 \pm 20(\mathrm{mg} / 100 \mathrm{~mL})$ of phenolic compounds. With the increase in the percentage of pomegranate juice, the amount of phenolic compounds significantly increased; the results are similar to the findings of Trigueros et al. [32]. Phenolic compounds are able to react with proteins, which depend on their concentration, $\mathrm{pH}$, and molecular weight. Low molecular weight phenolic compounds cannot produce strong cross-linking, but polymer types and high molecular weights are more active in cross-linking and are rapidly deposited by protein. Therefore, as the amount of pomegranate juice increased, the phenolic compounds were enhanced in cheese. Anthocyanins are extensively found in plant cell extracts and produce red, blue, and purple colors in 


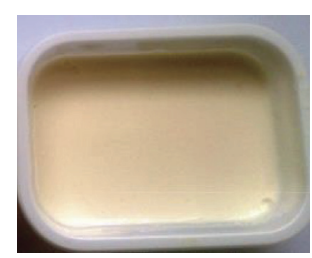

(a)

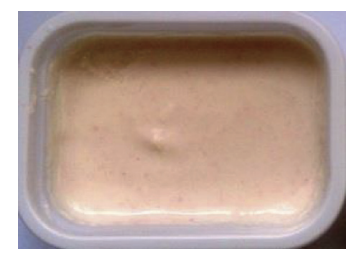

(b)

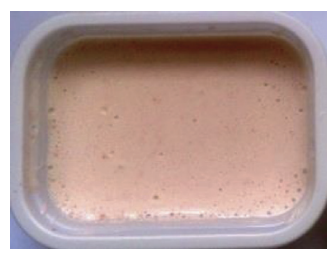

(c)

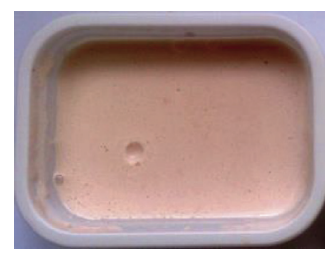

(d)

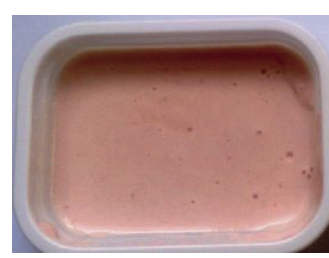

(e)

Figure 1: Pictures of surface Feta-type cheese containing different pomegranate juice concentrations. (a) $0 \%$. (b) $5 \%$. (c) $10 \%$. (d) $15 \%$. (e) $20 \%$.

many fruits and vegetables. Anthocyanins interact with each other and other pigments and proteins through hydrophobic and hydrogen bonds [33]. Pomegranate juice contains $27.22 \pm 0.23(\mathrm{mg} / 100 \mathrm{~mL})$ of anthocyanin. Therefore, it is expected that adding pomegranate juice to cheese causes the presence of this pigment in cheese.

The results showed that antioxidant activity significantly increased as the amount of pomegranate juice increased. Zarban et al. [8] found in their study that pomegranate juice has a higher inhibitory effect (96\%) than other fruits. Han et al. [10] also found that using phenolic compounds in cheese could enhance its antioxidant properties; they found that cheese with $0.15 \mathrm{mg} / \mathrm{mL}$ phenolic compounds had significant antioxidant properties. Also, similar results were achieved in the case of yogurt containing pomegranate juice, and the antioxidant properties of yogurt were increased with an increase in the amount of pomegranate juice. Phenolic compounds react with casein and whey protein, and affect their functional characteristics; various reports confirm that proteins exhibit antioxidant properties by interacting with phenolic compounds.

3.4.3. Oxidative Stability. The amount of free fatty acids in cheese represents the development of lipolysis. Lipolysis plays an important role in the development of the flavor of cheese. During the preparation and maturing of cheese, milk fat was hydrolyzed by the natural lipase of milk, lipolytic enzymes of starter and nonstarter bacteria, and lipase of psychrotrophic bacteria. The natural lipases of the milk are sensitive to heat; therefore, they are inactive in cheeses made from pasteurized milk and the essential lipolysis agent in these cheeses will be the starter and other bacteria. According to the results (Table 5), control samples have the highest FFA Index, which indicates that the inhibitory effect of pomegranate juice on the lipolysis by starters. Peroxide is the primary product of fat oxidation, and malondialdehyde is one of the secondary products of fat oxidation that is produced from the hydroperoxides in the second stages of oxidation. Pomegranate juice significantly decreased the peroxide value and the TBA index of cheese.

3.4.4. Textural Properties. Textural properties of cheese are shown in Table 6. Pomegranate juice reduced the hardness, cohesiveness, gumminess, chewiness, and springiness, and increased the adhesiveness of the sample. Water molecules and fat globules are located within the three-dimensional protein networks; if the amount of water increases, then the network structure will become weakened and more susceptible to deforming during compression [34]. According to the results, it can be said that pomegranate juice reduces dry matter and consequently the water in the cheese is increased; therefore, hardness and the amount of energy required for chewing the cheese was reduced. Moisture increases the plasticity of the protein matrix and decreases its elasticity. In addition, a lower protein density network has more adhesiveness and less cohesiveness. The reason for the reduction of cohesiveness is the weakness of the internal bonds in the structure of higher moisture cheeses and the softer tissue. These cheeses are easily irreversible deformed in the presence of pressure [35].

3.4.5. Color Properties. The main pigment in pomegranate juice is anthocyanin. The stability of anthocyanins is largely influenced by the chemical structure and concentration; the presence of oxygen, light, sugars, and enzymes; and the presence of complex compounds, $\mathrm{pH}$, ascorbic acid, and storage temperatures [36]. With an increase in the amount of pomegranate juice, the $\mathrm{L}$ and $\mathrm{b}$ significantly decreased and a significantly increased (Table 5). Therefore, it can be said that pomegranate juice reduces brightness and yellowness of the cheese and increases its redness due to the presence of anthocyanin compounds. The results were similar with the findings of Karaaslan et al. [37].

3.4.6. Microbial Properties. Microbial properties of cheese are shown in Table 7 . The survival rate of mesophilic and thermophilic Lactobacillus and Lactococcus were affected by the pomegranate juice. The number of starter significantly decreased with an increase in the amount of pomegranate juice. According to the results, the count of mesophilic was higher. Trigueros et al. [32] and Ranadheera et al. [38] also found similar results in terms of the impact of pomegranate juice on the survival of the Lactobacillus starter. The compounds of pomegranate juice inhibit the growth of starters and are important factors in reducing their populations. The acidity of pomegranate juice, the presence of high concentrations of phenolic compounds in pomegranate juice, and the antimicrobial properties of the pomegranate extract, which are attributed to tannins and flavonoids, are also effective factors in reducing the survival of microbial population, especially Gram-positive bacteria. 
TABLE 5: The physicochemical properties of Fruit whey less Feta-type cheeses produced using different percentages of pomegranate juice ( $\mathrm{S}_{0}$, $\mathrm{S}_{5}, \mathrm{~S}_{10}, \mathrm{~S}_{15}$, and $\mathrm{S}_{20}$, respectively, containing $0,5,10,15$, and $20 \%$ of pomegranate juice).

\begin{tabular}{|c|c|c|c|c|c|c|c|c|}
\hline Variables & Days & $\mathrm{S}_{0}$ & $\mathrm{~S}_{5}$ & $\mathrm{~S}_{10}$ & $\mathrm{~S}_{15}$ & $\mathrm{~S}_{20}$ & $P$ Treatment & $P$ Ripening \\
\hline \multirow{5}{*}{$\mathrm{pH}$} & 0 & $4.82^{\mathrm{Aa}}$ & $4.83^{\mathrm{Aa}}$ & $4.80^{\mathrm{Aa}}$ & $4.83^{\mathrm{Aa}}$ & $4.77^{\mathrm{Ba}}$ & $*$ & \multirow[t]{5}{*}{ 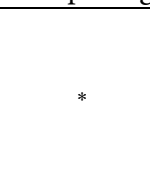 } \\
\hline & 15 & $4.78^{\mathrm{Ab}}$ & $4.75^{\mathrm{Bb}}$ & $4.68^{\mathrm{Cb}}$ & $4.78^{\mathrm{ABb}}$ & $4.68^{\mathrm{Cb}}$ & $*$ & \\
\hline & 30 & $4.68^{\mathrm{Ac}}$ & $4.60^{\mathrm{Bc}}$ & $4.65^{\mathrm{Cb}}$ & $4.67^{\mathrm{Dc}}$ & $4.58^{\mathrm{Ec}}$ & $*$ & \\
\hline & 45 & $4.66^{\mathrm{Ac}}$ & $4.58^{\mathrm{Bc}}$ & $4.55^{\mathrm{Cc}}$ & $4.58^{\mathrm{Bd}}$ & $4.44^{\mathrm{Dd}}$ & $*$ & \\
\hline & 60 & $4.57^{\mathrm{Ad}}$ & $4.50^{\mathrm{Bd}}$ & $4.52^{\mathrm{Bc}}$ & $4.53^{\mathrm{Be}}$ & $4.40^{\mathrm{Cd}}$ & $*$ & \\
\hline \multirow{5}{*}{ Syneresis (\%) } & 0 & $2.5^{\mathrm{Aa}}$ & $2.9^{\mathrm{Ba}}$ & $3.5^{\mathrm{Ca}}$ & $3.9^{\mathrm{Da}}$ & $4.2^{\mathrm{Ea}}$ & $*$ & \multirow{5}{*}{$*$} \\
\hline & 15 & $2.7^{\mathrm{Ab}}$ & $3.1^{\mathrm{Bab}}$ & $3.5^{\mathrm{Ca}}$ & $4.2^{\mathrm{Da}}$ & $4.6^{\mathrm{Eb}}$ & $*$ & \\
\hline & 30 & $3.0^{\mathrm{Ab}}$ & $3.4^{\mathrm{Bab}}$ & $3.7^{\mathrm{Ca}}$ & $4.1^{\mathrm{Da}}$ & $4.7^{\mathrm{Eb}}$ & $*$ & \\
\hline & 45 & $1.9^{\mathrm{Ac}}$ & $2.3^{\mathrm{Bc}}$ & $2.5^{\mathrm{Cb}}$ & $3.2^{\mathrm{Db}}$ & $3.4^{\mathrm{Ec}}$ & * & \\
\hline & 60 & $0.0^{\mathrm{Ad}}$ & $0.0^{\mathrm{Ad}}$ & $0.3^{\mathrm{Bc}}$ & $0.73^{\mathrm{Cc}}$ & $1.7^{\mathrm{Dd}}$ & $*$ & \\
\hline \multirow{5}{*}{ Dry matter (\%) } & 0 & $37.45^{\mathrm{Aa}}$ & $37.02^{\mathrm{Ba}}$ & $36.45^{\mathrm{Ca}}$ & $35.69^{\mathrm{Da}}$ & $35.11^{\mathrm{Ea}}$ & * & \multirow{5}{*}{ * } \\
\hline & 15 & $37.50^{\mathrm{Aab}}$ & $37.08^{\mathrm{Ba}}$ & $36.49^{\mathrm{Ca}}$ & $35.72^{\mathrm{Dab}}$ & $35.24^{\mathrm{Eb}}$ & $*$ & \\
\hline & 30 & $37.81^{\mathrm{Ab}}$ & $37.22^{\mathrm{Bb}}$ & $36.55^{\mathrm{Cb}}$ & $35.78^{\mathrm{Db}}$ & $35.35^{\mathrm{Ec}}$ & $*$ & \\
\hline & 45 & $37.24^{\mathrm{Ac}}$ & $36.68^{\mathrm{Bc}}$ & $35.95^{\mathrm{Cc}}$ & $35.25^{\mathrm{Dc}}$ & $34.45^{\mathrm{Ed}}$ & $*$ & \\
\hline & 60 & $36.69^{\mathrm{Ad}}$ & $35.86^{\mathrm{Bd}}$ & $35.28^{\mathrm{Cd}}$ & $34.32^{\mathrm{Dd}}$ & $34.24^{\mathrm{Ee}}$ & $*$ & \\
\hline \multirow{5}{*}{ Fat $(\%)$} & 0 & $16.27^{\mathrm{Aa}}$ & $15.39^{\mathrm{Ba}}$ & $14.92^{\mathrm{Ca}}$ & $14.66^{\mathrm{Da}}$ & $14.29^{\mathrm{Ea}}$ & $*$ & \multirow{5}{*}{ * } \\
\hline & 15 & $16.30^{\mathrm{Aa}}$ & $15.40^{\mathrm{Ba}}$ & $14.88^{\mathrm{Ca}}$ & $14.72^{\mathrm{Da}}$ & $14.35^{\mathrm{Ea}}$ & * & \\
\hline & 30 & $16.38^{\mathrm{Aa}}$ & $15.47^{\mathrm{Ba}}$ & $15.00^{\mathrm{Ca}}$ & $14.81^{\mathrm{Da}}$ & $14.38^{\mathrm{Ea}}$ & * & \\
\hline & 45 & $15.90^{\mathrm{Ab}}$ & $15.28^{\mathrm{Bb}}$ & $14.71^{\mathrm{Cb}}$ & $14.58^{\mathrm{Db}}$ & $14.19^{\mathrm{Eb}}$ & * & \\
\hline & 60 & $15.60^{\mathrm{A}}$ & $15.04^{\mathrm{Bc}}$ & $14.46^{\mathrm{Cc}}$ & $14.21^{\mathrm{Dc}}$ & $13.64^{\mathrm{Ec}}$ & $*$ & \\
\hline \multirow{5}{*}{ Salt (\%) } & 0 & $1.37^{\mathrm{Aa}}$ & $1.35^{\mathrm{Ba}}$ & $1.32^{\mathrm{Ca}}$ & $1.16^{\mathrm{Da}}$ & $1.12^{\mathrm{Ea}}$ & $*$ & \multirow{5}{*}{ * } \\
\hline & 15 & $1.36^{\mathrm{Ab}}$ & $1.33^{\mathrm{ABb}}$ & $1.30^{\mathrm{Ba}}$ & $1.13^{\mathrm{Cb}}$ & $1.08^{\mathrm{Db}}$ & $*$ & \\
\hline & 30 & $1.35^{\mathrm{Ab}}$ & $1.32^{\mathrm{Ab}}$ & $1.27^{\mathrm{Bb}}$ & $1.17^{\mathrm{Ca}}$ & $1.07^{\mathrm{Db}}$ & $*$ & \\
\hline & 45 & $1.39^{\mathrm{Ac}}$ & $1.36^{\mathrm{Ba}}$ & $1.31^{\mathrm{Ca}}$ & $1.21^{\mathrm{Dc}}$ & $1.14^{\mathrm{Ea}}$ & $*$ & \\
\hline & 60 & $1.45^{\mathrm{Ad}}$ & $1.40^{\mathrm{Bc}}$ & $1.34^{\mathrm{Cc}}$ & $1.27^{\mathrm{Dd}}$ & $1.20^{\mathrm{Ec}}$ & $*$ & \\
\hline \multirow{5}{*}{ Ash (\%) } & 0 & 3.55 & 3.40 & 3.26 & 3.18 & 3.04 & $*$ & \multirow{5}{*}{ ns } \\
\hline & 15 & 3.48 & 3.54 & 3.24 & 3.12 & 3.15 & $*$ & \\
\hline & 30 & 3.45 & 3.39 & 3.32 & 3.09 & 3.07 & $*$ & \\
\hline & 45 & 3.49 & 3.36 & 3.24 & 3.07 & 3.06 & $*$ & \\
\hline & 60 & 3.41 & 3.30 & 3.16 & 3.10 & 2.99 & * & \\
\hline \multirow{5}{*}{ Total protein $(\%)$} & 0 & $12.38^{\mathrm{Aa}}$ & $11.80^{\mathrm{Ba}}$ & $11.38^{\mathrm{Ca}}$ & $10.93^{\mathrm{Da}}$ & $10.32^{\mathrm{Ea}}$ & $*$ & \multirow{5}{*}{ * } \\
\hline & 15 & $12.39^{\mathrm{Aa}}$ & $11.94^{\mathrm{Ba}}$ & $11.36^{\mathrm{Ca}}$ & $10.95^{\mathrm{Da}}$ & $10.31^{\mathrm{Ea}}$ & $*$ & \\
\hline & 30 & $12.43^{\mathrm{Aa}}$ & $11.95^{\mathrm{Ba}}$ & $11.39^{\mathrm{Ca}}$ & $11.00^{\mathrm{Da}}$ & $10.28^{\mathrm{Eb}}$ & $*$ & \\
\hline & 45 & $12.13^{\mathrm{Ab}}$ & $11.70^{\mathrm{Bb}}$ & $11.31^{\mathrm{Cb}}$ & $10.93^{\mathrm{Da}}$ & $10.10^{\mathrm{Ec}}$ & * & \\
\hline & 60 & $12.06^{\mathrm{Ac}}$ & $11.50^{\mathrm{BC}}$ & $10.88^{\mathrm{Cc}}$ & $10.58^{\mathrm{Db}}$ & $9.99^{\mathrm{Ec}}$ & * & \\
\hline \multirow{5}{*}{ Nonprotein nitrogen/total protein } & 0 & $2.26^{\mathrm{Aa}}$ & $2.05^{\mathrm{Ba}}$ & $1.90^{\mathrm{Ba}}$ & $1.85^{\mathrm{BCa}}$ & $1.80^{\mathrm{Ca}}$ & * & \multirow{5}{*}{ * } \\
\hline & 15 & $3.05^{\mathrm{Ab}}$ & $2.28^{\mathrm{Bb}}$ & $2.55^{\mathrm{Bb}}$ & $2.70^{\mathrm{Bb}}$ & $2.48^{\mathrm{Cb}}$ & * & \\
\hline & 30 & $4.66^{\mathrm{Ac}}$ & $2.55^{\mathrm{Bc}}$ & $3.50^{\mathrm{Bc}}$ & $3.15^{\mathrm{Cc}}$ & $3.05^{\mathrm{Dc}}$ & $*$ & \\
\hline & 45 & $6.53^{\mathrm{Ad}}$ & $3.78^{\mathrm{Bd}}$ & $3.85^{\mathrm{Bd}}$ & $3.82^{\mathrm{Bd}}$ & $3.35^{\mathrm{Cd}}$ & * & \\
\hline & 60 & $7.63^{\mathrm{Ae}}$ & $4.90^{\mathrm{Be}}$ & $4.35^{\mathrm{Ce}}$ & $4.03^{\mathrm{De}}$ & $3.85^{\mathrm{De}}$ & * & \\
\hline \multirow{5}{*}{ Total phenol (mg/g of cheese) } & 0 & $0.078^{\mathrm{Aa}}$ & $0.148^{\mathrm{Ba}}$ & $0.252^{\mathrm{Ca}}$ & $0.353^{\mathrm{Da}}$ & $0.443^{\mathrm{Ea}}$ & $*$ & \\
\hline & 15 & $0.072^{\mathrm{Aa}}$ & $0.118^{\mathrm{Bb}}$ & $0.173^{\mathrm{Cb}}$ & $0.290^{\mathrm{Db}}$ & $0.378^{\mathrm{Eb}}$ & * & \\
\hline & 30 & $0.036^{\mathrm{Ab}}$ & $0.067^{\mathrm{Bc}}$ & $0.093^{\mathrm{Cc}}$ & $0.225^{\mathrm{Dc}}$ & $0.293^{\mathrm{Ec}}$ & * & $*$ \\
\hline & 45 & $0.024^{\mathrm{Ac}}$ & $0.027^{\mathrm{Ad}}$ & $0.063^{\mathrm{Bd}}$ & $0.147^{\mathrm{Cd}}$ & $0.203^{\mathrm{Dd}}$ & $*$ & \\
\hline & 60 & $0.014^{\mathrm{Ad}}$ & $0.016^{\mathrm{Ae}}$ & $0.049^{\mathrm{Be}}$ & $0.102^{\mathrm{Cc}}$ & $0.183^{\mathrm{De}}$ & $*$ & \\
\hline & 0 & $0^{\mathrm{Aa}}$ & $0.013^{\mathrm{Ba}}$ & $0.023^{\mathrm{Ca}}$ & $0.038^{\mathrm{Da}}$ & $0.049^{\mathrm{Ea}}$ & $*$ & \\
\hline & 15 & $0^{\mathrm{Aa}}$ & $0.007^{\mathrm{Bb}}$ & $0.018^{\mathrm{Cb}}$ & $0.034^{\mathrm{Db}}$ & $0.041^{\mathrm{Eb}}$ & * & \\
\hline Anthocyanin (mg/g of cheese) & 30 & $0^{\mathrm{Aa}}$ & $0.003^{\mathrm{Bc}}$ & $0.011^{\mathrm{Cc}}$ & $0.030^{\mathrm{Dc}}$ & $0.033^{\mathrm{Ec}}$ & * & * \\
\hline & 45 & $0^{\mathrm{Aa}}$ & $0^{\text {Ad }}$ & $0.008^{\mathrm{Bd}}$ & $0.022^{\mathrm{Cd}}$ & $0.027^{\mathrm{Dd}}$ & $*$ & \\
\hline & 60 & $0^{\mathrm{Aa}}$ & $0^{\mathrm{Ad}}$ & $0.003^{\mathrm{Be}}$ & $0.018^{\mathrm{Ce}}$ & $0.024^{\mathrm{Dd}}$ & * & \\
\hline & 0 & $5.54^{\mathrm{Aa}}$ & $20.20^{\mathrm{Ba}}$ & $30.33^{\mathrm{Ca}}$ & $42.10^{\mathrm{Da}}$ & $53.99^{\mathrm{Ea}}$ & $*$ & \\
\hline & 15 & $7.03^{\mathrm{Ab}}$ & $18.00^{\mathrm{Bb}}$ & $27.16^{\mathrm{Cb}}$ & $34.92^{\mathrm{Db}}$ & $39.72^{\mathrm{Eb}}$ & $*$ & \\
\hline Radical inhibition \% & 30 & $8.34^{\mathrm{Ac}}$ & $15.16^{\mathrm{Bc}}$ & $20.11^{\mathrm{Cc}}$ & $21.30^{\mathrm{Cc}}$ & $20.89^{\mathrm{Cc}}$ & $*$ & * \\
\hline & 45 & $9.01^{\mathrm{Ad}}$ & $11.50^{\mathrm{Bd}}$ & $12.72^{\mathrm{Cd}}$ & $17.95^{\mathrm{Dd}}$ & $18.28^{\mathrm{Ed}}$ & $*$ & \\
\hline & 60 & $9.74^{\mathrm{Ae}}$ & $9.25^{\mathrm{Ae}}$ & $11.78^{\mathrm{Be}}$ & $15.36^{\mathrm{Ce}}$ & $17.33^{\mathrm{De}}$ & $*$ & \\
\hline
\end{tabular}


TABLE 5: Continued.

\begin{tabular}{|c|c|c|c|c|c|c|c|c|}
\hline Variables & Days & $\mathrm{S}_{0}$ & $\mathrm{~S}_{5}$ & $\mathrm{~S}_{10}$ & $\mathrm{~S}_{15}$ & $\mathrm{~S}_{20}$ & $P$ Treatment & $P$ Ripening \\
\hline \multirow{5}{*}{ Ferry fatty acid (meq/100 g fat) } & 0 & $0.30^{\mathrm{Aa}}$ & $0.27^{\mathrm{Ba}}$ & $0.25^{\mathrm{Ca}}$ & $0.20^{\mathrm{Da}}$ & $0.19^{\mathrm{Da}}$ & $*$ & \multirow{5}{*}{$\begin{array}{llll}0 & 1 & 0\end{array}$} \\
\hline & 15 & $0.35^{\mathrm{Ab}}$ & $0.28^{\mathrm{Ba}}$ & $0.27^{\mathrm{Bab}}$ & $0.22^{\mathrm{Ca}}$ & $0.20^{\mathrm{Cb}}$ & $*$ & \\
\hline & 30 & $0.51^{\mathrm{Ac}}$ & $0.29^{\mathrm{Ba}}$ & $0.28^{\mathrm{Bb}}$ & $0.25^{\mathrm{Cb}}$ & $0.24^{\mathrm{Cc}}$ & $*$ & \\
\hline & 45 & $0.65^{\text {Ad }}$ & $0.32^{\mathrm{Bb}}$ & $0.30^{\mathrm{BCc}}$ & $0.28^{\mathrm{Cc}}$ & $0.27^{\mathrm{Cd}}$ & * & \\
\hline & 60 & $0.78^{\mathrm{Ae}}$ & $0.36^{\mathrm{Bc}}$ & $0.33^{\mathrm{Cd}}$ & $0.32^{\mathrm{Cd}}$ & $0.33^{\mathrm{Ce}}$ & $*$ & \\
\hline \multirow{5}{*}{ Peroxide value (meq $\mathrm{g} \mathrm{o}_{2} / \mathrm{kg}$ fat) } & 0 & $0.130^{\mathrm{Aa}}$ & $0.125^{\mathrm{ABa}}$ & $0.120^{\mathrm{BCa}}$ & $0.115^{\mathrm{Da}}$ & $0.095^{\mathrm{Ea}}$ & $*$ & \multirow{5}{*}{$*$} \\
\hline & 15 & $0.150^{\mathrm{Ab}}$ & $0.150^{\mathrm{Ab}}$ & $0.150^{\mathrm{Ab}}$ & $0.130^{\mathrm{Bb}}$ & $0.135^{\mathrm{Bb}}$ & $*$ & \\
\hline & 30 & $0.200^{\mathrm{Ac}}$ & $0.195^{\mathrm{Ac}}$ & $0.190^{\mathrm{Ac}}$ & $0.170^{\mathrm{Bc}}$ & $0.150^{\mathrm{Cc}}$ & $*$ & \\
\hline & 45 & $0.250^{\mathrm{Ad}}$ & $0.245^{\mathrm{Ad}}$ & $0.240^{\mathrm{Ad}}$ & $0.220^{\mathrm{Bd}}$ & $0.225^{\mathrm{Bd}}$ & $*$ & \\
\hline & 60 & $0.310^{\mathrm{Ae}}$ & $0.300^{\mathrm{Ae}}$ & $0.295^{\mathrm{Ae}}$ & $0.275^{\mathrm{Be}}$ & $0.250^{\mathrm{Ce}}$ & $*$ & \\
\hline \multirow{5}{*}{ Thiobarbituric acid index (ppm) } & 0 & $0.195^{\mathrm{Aa}}$ & $0.180^{\mathrm{ABa}}$ & $0.175^{\mathrm{Ba}}$ & $0.150^{\mathrm{Ca}}$ & $0.070^{\mathrm{Da}}$ & * & \multirow{5}{*}{$*$} \\
\hline & 15 & $0.575^{\mathrm{Ab}}$ & $0.450^{\mathrm{ABb}}$ & $0.500^{\mathrm{Bb}}$ & $0.410^{\mathrm{Cb}}$ & $0.220^{\mathrm{Db}}$ & $*$ & \\
\hline & 30 & $1.015^{\mathrm{Ac}}$ & $1.115^{\mathrm{Ac}}$ & $0.940^{\mathrm{Bc}}$ & $0.925^{\mathrm{Cc}}$ & $0.800^{\mathrm{Dc}}$ & $*$ & \\
\hline & 45 & $1.650^{\mathrm{Ad}}$ & $1.700^{\mathrm{ABd}}$ & $1.550^{\mathrm{Bd}}$ & $1.425^{\mathrm{Cd}}$ & $1.250^{\mathrm{Dd}}$ & $*$ & \\
\hline & 60 & $2.135^{\mathrm{Ae}}$ & $1.990^{\mathrm{Be}}$ & $1.865^{\mathrm{Ce}}$ & $1.815^{\mathrm{De}}$ & $1.470^{\mathrm{Ee}}$ & * & \\
\hline \multirow{5}{*}{$\mathrm{L}^{*}$} & 0 & $62.25^{\mathrm{Aa}}$ & $57.55^{\mathrm{Ba}}$ & $55.30^{\mathrm{Ca}}$ & $53.95^{\mathrm{Da}}$ & $51.30^{\mathrm{Ea}}$ & $*$ & \multirow{5}{*}{$*$} \\
\hline & 15 & $61.75^{\mathrm{Ab}}$ & $56.55^{\mathrm{Bb}}$ & $54.60^{\mathrm{Cb}}$ & $52.90^{\mathrm{Db}}$ & $50.50^{\mathrm{Eb}}$ & $*$ & \\
\hline & 30 & $60.50^{\mathrm{Ac}}$ & $55.60^{\mathrm{Bc}}$ & $54.10^{\mathrm{Cb}}$ & $52.45^{\mathrm{Db}}$ & $50.80^{\mathrm{Eb}}$ & $*$ & \\
\hline & 45 & $59.05^{\mathrm{Ac}}$ & $55.10^{\mathrm{Bc}}$ & $53.80^{\mathrm{Cc}}$ & $50.95^{\mathrm{Dc}}$ & $49.00^{\mathrm{Dc}}$ & * & \\
\hline & 60 & $58.35^{\mathrm{Ad}}$ & $54.25^{\mathrm{Bd}}$ & $52.75^{\mathrm{Bd}}$ & $50.10^{\mathrm{Cc}}$ & $48.35^{\mathrm{Ed}}$ & $*$ & \\
\hline \multirow{5}{*}{$b^{*}$} & 0 & $17.45^{\mathrm{Ad}}$ & $15.65^{\mathrm{Bd}}$ & $14.95^{\mathrm{Bd}}$ & $14.05^{\mathrm{Cc}}$ & $13.20^{\mathrm{Dd}}$ & * & \multirow{5}{*}{$*$} \\
\hline & 15 & $18.05^{\mathrm{Ac}}$ & $15.90^{\mathrm{Bc}}$ & $15.10^{\mathrm{Bc}}$ & $14.10^{\mathrm{Cbc}}$ & $13.45^{\mathrm{Dc}}$ & $*$ & \\
\hline & 30 & $18.20^{\mathrm{Ab}}$ & $16.15^{\mathrm{Bbc}}$ & $15.50^{\mathrm{Bc}}$ & $14.55^{\mathrm{Cb}}$ & $13.70^{\mathrm{Dc}}$ & $*$ & \\
\hline & 45 & $18.50^{\mathrm{Ab}}$ & $16.45^{\mathrm{Bb}}$ & $16.60^{\mathrm{Bb}}$ & $15.20^{\mathrm{Ca}}$ & $14.15^{\mathrm{Db}}$ & $*$ & \\
\hline & 60 & $19.65^{\mathrm{Aa}}$ & $16.95^{\mathrm{Ba}}$ & $17.20^{\mathrm{Ba}}$ & $15.15^{\mathrm{Ca}}$ & $14.40^{\mathrm{Da}}$ & $*$ & \\
\hline \multirow{5}{*}{$a^{*}$} & 0 & $2.50^{\mathrm{Ea}}$ & $4.10^{\mathrm{Da}}$ & $5.75^{\mathrm{Ca}}$ & $7.30^{\mathrm{Ba}}$ & $7.75^{\mathrm{Aa}}$ & $*$ & \multirow{5}{*}{$*$} \\
\hline & 15 & $2.35^{\mathrm{Eb}}$ & $3.55^{\mathrm{Db}}$ & $5.15^{\mathrm{Cb}}$ & $7.20^{\mathrm{Bb}}$ & $7.40^{\mathrm{Ab}}$ & $*$ & \\
\hline & 30 & $2.35^{\mathrm{Eb}}$ & $3.25^{\mathrm{Db}}$ & $4.55^{\mathrm{Cc}}$ & $6.70^{\mathrm{Bc}}$ & $7.20^{\mathrm{Ac}}$ & $*$ & \\
\hline & 45 & $2.05^{\mathrm{Ec}}$ & $2.45^{\mathrm{Dc}}$ & $4.50^{\mathrm{Cc}}$ & $5.65^{\mathrm{Bd}}$ & $7.20^{\mathrm{Ac}}$ & $*$ & \\
\hline & 60 & $1.80^{\mathrm{Ed}}$ & $2.30^{\mathrm{Dc}}$ & $3.65^{\mathrm{Cd}}$ & $5.40^{\mathrm{Bd}}$ & $5.85^{\mathrm{Ad}}$ & $*$ & \\
\hline
\end{tabular}

ns, nonsignificant, ${ }^{*} p \leq 0.05$. Means within each row with different uppercase letters are significantly different $(p \leq 0.05)$, and means within each column with different lowercase letters are significantly different $(p<0.05)$.

TABLE 6: The textural properties of Fruit whey less Feta-type cheeses produced using different percentages of pomegranate juice $\left(S_{0}\right.$, $S_{5}$, $S_{10}$, $S_{15}$, and $S_{20}$, respectively, containing $0,5,10,15$, and $20 \%$ of pomegranate juice).

\begin{tabular}{|c|c|c|c|c|c|c|c|c|}
\hline Variables & Days & $\mathrm{S}_{0}$ & $\mathrm{~S}_{5}$ & $\mathrm{~S}_{10}$ & $\mathrm{~S}_{15}$ & $\mathrm{~S}_{20}$ & $P$ Treatment & $P$ Ripening \\
\hline \multirow{5}{*}{ Hardness (g) } & 0 & $1038^{\mathrm{Aa}}$ & $826.0^{\mathrm{Ba}}$ & $599.5^{\mathrm{Ca}}$ & $587.5^{\mathrm{Ca}}$ & $476.5^{\mathrm{Da}}$ & $*$ & \multirow{5}{*}{$\begin{array}{llll}0 & 1 \\
\end{array}$} \\
\hline & 15 & $1079^{\mathrm{Ab}}$ & $860.0^{\mathrm{Bb}}$ & $760.0^{\mathrm{Cb}}$ & $732.5^{\mathrm{Cb}}$ & $510.0^{\mathrm{Db}}$ & * & \\
\hline & 30 & $1034^{\mathrm{Ab}}$ & $952.5^{\mathrm{Bc}}$ & $778.5^{\mathrm{Cb}}$ & $695.0^{\mathrm{Cb}}$ & $539.5^{\mathrm{Db}}$ & $*$ & \\
\hline & 45 & $983.5^{\mathrm{Aa}}$ & $801.0^{\mathrm{Ba}}$ & $644.5^{\mathrm{Cc}}$ & $641.5^{\mathrm{Cc}}$ & $384.0^{\mathrm{Dc}}$ & $*$ & \\
\hline & 60 & $944.5^{\mathrm{Ac}}$ & $727.0^{\mathrm{Bd}}$ & $619.0^{\mathrm{Ca}}$ & $540.0^{\mathrm{Da}}$ & $302.8^{\mathrm{Ed}}$ & * & \\
\hline \multirow{5}{*}{ Cohesiveness } & 0 & $0.555^{\mathrm{Aa}}$ & $0.530^{\mathrm{Ba}}$ & $0.380^{\mathrm{Ca}}$ & $0.390^{\mathrm{Ca}}$ & $0.350^{\mathrm{Ca}}$ & * & \multirow{5}{*}{ * } \\
\hline & 15 & $0.618^{\mathrm{Ab}}$ & $0.525^{\mathrm{Bb}}$ & $0.435^{\mathrm{Cb}}$ & $0.415^{\mathrm{Cb}}$ & $0.475^{\mathrm{Cb}}$ & * & \\
\hline & 30 & $0.625^{\mathrm{Ab}}$ & $0.555^{\mathrm{Bb}}$ & $0.550^{\mathrm{Bb}}$ & $0.490^{\mathrm{Cb}}$ & $0.425^{\mathrm{Cb}}$ & $*$ & \\
\hline & 45 & $0.550^{\text {Aac }}$ & $0.415^{\mathrm{Bc}}$ & $0.365^{\mathrm{Cac}}$ & $0.380^{\mathrm{Cac}}$ & $0.340^{\mathrm{Cac}}$ & * & \\
\hline & 60 & $0.410^{\mathrm{Ad}}$ & $0.415^{\mathrm{Ac}}$ & $0.305^{\mathrm{Cd}}$ & $0.305^{\mathrm{Cd}}$ & $0.280^{\mathrm{Cd}}$ & * & \\
\hline \multirow{5}{*}{ Gumminess (g) } & 0 & $591.5^{\mathrm{Aa}}$ & $436.6^{\mathrm{Bab}}$ & $282.5^{\mathrm{Cab}}$ & $237.5^{\mathrm{Dab}}$ & $188.3^{\text {Eab }}$ & $*$ & \multirow{5}{*}{ * } \\
\hline & 15 & $615.4^{\mathrm{Aa}}$ & $437.5^{\mathrm{Bb}}$ & $325.0^{\mathrm{Cb}}$ & $253.5^{\mathrm{Db}}$ & $190.7^{\mathrm{Eb}}$ & $*$ & \\
\hline & 30 & $592.5^{\mathrm{Aa}}$ & $441.0^{\mathrm{Bb}}$ & $295.5^{\mathrm{Cb}}$ & $252.5^{\mathrm{Db}}$ & $205.0^{\mathrm{Eb}}$ & * & \\
\hline & 45 & $525.0^{\mathrm{Ab}}$ & $432.5^{\mathrm{Bb}}$ & $322.5^{\mathrm{Cb}}$ & $272.5^{\mathrm{Db}}$ & $204.0^{\mathrm{Eb}}$ & * & \\
\hline & 60 & $517.0^{\mathrm{Ac}}$ & $395.0^{\mathrm{Bb}}$ & $282.0^{\mathrm{Ca}}$ & $227.5^{\mathrm{Da}}$ & $160.5^{\mathrm{Ea}}$ & $*$ & \\
\hline \multirow{5}{*}{ Chewiness (mj) } & 0 & $44.29^{\mathrm{Aa}}$ & $37.56^{\mathrm{Aa}}$ & $33.00^{\mathrm{Ba}}$ & $25.00^{\mathrm{Ba}}$ & $17.16^{\mathrm{Ca}}$ & * & \multirow{5}{*}{ * } \\
\hline & 15 & $34.50^{\mathrm{Aab}}$ & $33.53^{\mathrm{Aab}}$ & $29.14^{\mathrm{Ba}}$ & $23.50^{\mathrm{Bab}}$ & $17.15^{\mathrm{Cab}}$ & * & \\
\hline & 30 & $29.06^{\mathrm{Aab}}$ & $32.00^{\mathrm{Aab}}$ & $26.00^{\mathrm{Bb}}$ & $25.50^{\mathrm{Bab}}$ & $15.11^{\mathrm{Cab}}$ & * & \\
\hline & 45 & $23.64^{\mathrm{Ab}}$ & $31.25^{\mathrm{Ab}}$ & $25.00^{\mathrm{Bb}}$ & $21.50^{\mathrm{Bb}}$ & $12.25^{\mathrm{Cb}}$ & $*$ & \\
\hline & 60 & $25.00^{\mathrm{Ab}}$ & $30.5^{\mathrm{Ab}}$ & $21.00^{\mathrm{Bd}}$ & $15.115^{\mathrm{Bc}}$ & $11.00^{\mathrm{Cb}}$ & $*$ & \\
\hline
\end{tabular}


TABLE 6: Continued.

\begin{tabular}{|c|c|c|c|c|c|c|c|c|}
\hline Variables & Days & $\mathrm{S}_{0}$ & $\mathrm{~S}_{5}$ & $\mathrm{~S}_{10}$ & $\mathrm{~S}_{15}$ & $\mathrm{~S}_{20}$ & $P$ Treatment & $P$ Ripening \\
\hline \multirow{5}{*}{ Springiness $(\mathrm{mm})$} & 0 & 4.0 & 3.7 & 3.3 & 3.2 & 3.1 & $*$ & \multirow{5}{*}{ ns } \\
\hline & 15 & 3.8 & 3.5 & 3.3 & 3.0 & 3.0 & $*$ & \\
\hline & 30 & 3.5 & 3.5 & 3.1 & 3.3 & 2.8 & $*$ & \\
\hline & 45 & 3.5 & 3.5 & 3.2 & 3.2 & 2.7 & $*$ & \\
\hline & 60 & 3.3 & 3.4 & 3.2 & 3.1 & 2.6 & $*$ & \\
\hline \multirow{5}{*}{ Adhesiveness (mj) } & 0 & $1.00^{\mathrm{Aa}}$ & $1.37^{\mathrm{Ba}}$ & $1.56^{\mathrm{Ba}}$ & $1.69^{\mathrm{Ca}}$ & $1.95^{\mathrm{Ca}}$ & * & \multirow{5}{*}{$*$} \\
\hline & 15 & $1.00^{\mathrm{Aa}}$ & $1.35^{\mathrm{Ba}}$ & $1.52^{\mathrm{Ba}}$ & $1.70^{\mathrm{Ca}}$ & $1.89^{\mathrm{Ca}}$ & * & \\
\hline & 30 & $1.25^{\mathrm{Ab}}$ & $1.52^{\mathrm{Bb}}$ & $1.53^{\mathrm{Bab}}$ & $1.93^{\mathrm{Cb}}$ & $2.06^{\mathrm{Cab}}$ & $*$ & \\
\hline & 45 & $1.23^{\mathrm{Ab}}$ & $1.55^{\mathrm{Bb}}$ & $1.35^{\mathrm{Bab}}$ & $2.15^{\mathrm{Cb}}$ & $2.15^{\mathrm{Cab}}$ & $*$ & \\
\hline & 60 & $1.20^{\mathrm{Ab}}$ & $1.65^{\mathrm{Bb}}$ & $1.75^{\mathrm{Bb}}$ & $2.07^{\mathrm{Cb}}$ & $2.38^{\mathrm{Db}}$ & $*$ & \\
\hline
\end{tabular}

ns, nonsignificant, ${ }^{*} p \leq 0.05$. Means within each row with different uppercase letters are significantly different $(p<0.05)$, and means within each column with different lowercase letters are significantly different $(p<0.05)$.

TABLE 7: The microbial properties of Fruit whey less Feta-type cheeses produced using different percentages of pomegranate juice $\left(S_{0}\right.$, $S_{5}, S_{10}$, $S_{15}$, and $S_{20}$, respectively, containing $0,5,10,15$, and $20 \%$ of pomegranate juice).

\begin{tabular}{|c|c|c|c|c|c|c|c|c|}
\hline Variables & Days & $\mathrm{S}_{0}$ & $\mathrm{~S}_{5}$ & $\mathrm{~S}_{10}$ & $\mathrm{~S}_{15}$ & $\mathrm{~S}_{20}$ & $P$ Treatment & $P$ Ripening \\
\hline \multirow{5}{*}{ Mesophilic lactobacilli $\left(\log _{10} \mathrm{cfu} / \mathrm{g}\right)$} & 0 & $8.43^{\mathrm{Aa}}$ & $8.33^{\mathrm{Ba}}$ & $7.65^{\mathrm{Ca}}$ & $7.15^{\mathrm{Da}}$ & $6.59^{\mathrm{Ea}}$ & $*$ & \multirow[t]{5}{*}{$4 \mathrm{C}_{2}$} \\
\hline & 15 & $8.28^{\mathrm{Aa}}$ & $8.23^{\mathrm{Aa}}$ & $7.58^{\mathrm{Ba}}$ & $7.03^{\mathrm{Ca}}$ & $6.49^{\mathrm{Db}}$ & $*$ & \\
\hline & 30 & $8.06^{\mathrm{Ab}}$ & $7.58^{\mathrm{Bb}}$ & $7.38^{\mathrm{Cb}}$ & $6.88^{\mathrm{Db}}$ & $6.48^{\mathrm{Eb}}$ & * & \\
\hline & 45 & $7.82^{\mathrm{Ac}}$ & $7.50^{\mathrm{Bb}}$ & $6.89^{\mathrm{Cc}}$ & $6.43^{\mathrm{Dc}}$ & $6.30^{\mathrm{Ec}}$ & * & \\
\hline & 60 & $7.47^{\mathrm{Ad}}$ & $7.11^{\mathrm{Bc}}$ & $6.24^{\mathrm{Cd}}$ & $6.12^{\mathrm{Dd}}$ & $5.84^{\mathrm{Ed}}$ & * & \\
\hline \multirow{5}{*}{ Thermophilic lactobacilli $\left(\log _{10} \mathrm{cfu} / \mathrm{g}\right)$} & 0 & $7.54^{\mathrm{Aa}}$ & $7.03^{\mathrm{Ba}}$ & $6.95^{\mathrm{Ba}}$ & $6.09^{\mathrm{Ca}}$ & $5.99^{\mathrm{Da}}$ & * & \multirow{5}{*}{ * } \\
\hline & 15 & $7.14^{\mathrm{Ab}}$ & $6.93^{\mathrm{Bb}}$ & $6.88^{\mathrm{Bb}}$ & $5.78^{\mathrm{Cb}}$ & $5.54^{\mathrm{Db}}$ & $*$ & \\
\hline & 30 & $6.89^{\mathrm{Ac}}$ & $6.10^{\mathrm{Bc}}$ & $6.11^{\mathrm{Bc}}$ & $5.87^{\mathrm{Cb}}$ & $5.47^{\mathrm{Dc}}$ & $*$ & \\
\hline & 45 & $6.75^{\mathrm{Ad}}$ & $5.70^{\mathrm{Ad}}$ & $5.86^{\mathrm{Ad}}$ & $5.50^{\mathrm{Bc}}$ & $5.23^{\mathrm{Cd}}$ & * & \\
\hline & 60 & $6.12^{\mathrm{Ae}}$ & $5.24^{\mathrm{Be}}$ & $5.08^{\mathrm{Ce}}$ & $5.06^{\mathrm{Cd}}$ & $4.91^{\mathrm{De}}$ & * & \\
\hline \multirow{5}{*}{ Mesophilic lactococci $\left(\log _{10} \mathrm{cfu} / \mathrm{g}\right)$} & 0 & $8.42^{\mathrm{Aa}}$ & $8.11^{\mathrm{Aa}}$ & $7.62^{\mathrm{Ba}}$ & $7.27^{\mathrm{Ca}}$ & $6.64^{\mathrm{Da}}$ & $*$ & \multirow{5}{*}{$*$} \\
\hline & 15 & $8.41^{\mathrm{Aa}}$ & $8.24^{\mathrm{Aa}}$ & $7.57^{\mathrm{Ba}}$ & $7.11^{\mathrm{Ca}}$ & $6.40^{\mathrm{Da}}$ & $*$ & \\
\hline & 30 & $7.73^{\mathrm{Ab}}$ & $7.79^{\mathrm{Ab}}$ & $7.10^{\mathrm{Bb}}$ & $6.732^{\mathrm{Cb}}$ & $6.00^{\mathrm{Db}}$ & * & \\
\hline & 45 & $7.46^{\mathrm{Ac}}$ & $7.34^{\mathrm{Ac}}$ & $6.94^{\mathrm{Bc}}$ & $6.42^{\mathrm{Cc}}$ & $5.49^{\mathrm{Dc}}$ & * & \\
\hline & 60 & $7.05^{\mathrm{Ad}}$ & $6.83^{\mathrm{Ad}}$ & $6.50^{\mathrm{Bd}}$ & $6.02^{\mathrm{Cd}}$ & $5.06^{\mathrm{Dd}}$ & $*$ & \\
\hline \multirow{5}{*}{ Thermophilic lactococci $\left(\log _{10} \mathrm{cfu} / \mathrm{g}\right)$} & 0 & $8.40^{\mathrm{Aa}}$ & $7.70^{\mathrm{Ba}}$ & $7.00^{\mathrm{Ca}}$ & $6.84^{\mathrm{Ca}}$ & $6.60^{\mathrm{Ca}}$ & * & \multirow{5}{*}{ * } \\
\hline & 15 & $8.18^{\mathrm{Ab}}$ & $7.13^{\mathrm{Bb}}$ & $6.53^{\mathrm{Cb}}$ & $6.53^{\mathrm{Cb}}$ & $6.46^{\mathrm{Cb}}$ & * & \\
\hline & 30 & $7.45^{\mathrm{Ac}}$ & $7.07^{\mathrm{Bc}}$ & $6.11^{\mathrm{Cc}}$ & $6.01^{\mathrm{Cc}}$ & $6.02^{\mathrm{Cc}}$ & * & \\
\hline & 45 & $7.15^{\mathrm{Ad}}$ & $6.40^{\mathrm{Bd}}$ & $5.09^{\mathrm{Cd}}$ & $5.22^{\mathrm{Cd}}$ & $5.29^{\mathrm{Cd}}$ & * & \\
\hline & 60 & $6.935^{\mathrm{Ae}}$ & $5.93^{\mathrm{Be}}$ & $4.88^{\mathrm{Ce}}$ & $4.54^{\mathrm{Ce}}$ & $4.43^{\mathrm{Ce}}$ & $*$ & \\
\hline
\end{tabular}

ns, nonsignificant, ${ }^{*} p \leq 0.05$. Means within each row with different uppercase letters are significantly different $(p<0.05)$, and means within each column with different lowercase letters are significantly different $(p<0.05)$.

3.4.7. Sensory Attributes. One of the important characteristics of a food product is consumer acceptability. In this test, the surface color, internal color, surface appearance, internal appearance, texture, flavor, and acceptance of the samples were evaluated (Figure 2). The sample containing $20 \%$ of pomegranate juice has the highest rating of acceptance, surface color, internal color, and surface appearance and taste. In all cases, the sensory scores for the color of the internal texture was less than the surface color of the cheese. The surface appearance of samples was examined for porosity and flatness. The internal surface of the sample was examined after cutting, in order to investigate its porosity, smoothness, and homogeneity. Results indicated that the internal appearance of the samples were similar. The texture score of the samples showed that the more the pomegranate juice, the lower the score of the tissue. The findings of the texture analysis (Table 6) also confirmed the loss of texture in the sample with $20 \%$ pomegranate juice. The flavor of cheese is influenced by the formulation components and the complex biochemical reactions during storage that are carried out by the enzymes present in milk, cheese, and natural microorganisms and starters. Proteolysis, lipolysis, and glycolysis are major reactions that occur during storage. The proteolysis process has the greatest effect on flavor due to the production of free peptides and amino acids that contain flavoring compounds, such as amines, acids, thiols, and thioesters [39]. According to the panelists, samples containing 15 and $20 \%$ pomegranate juice have the highest flavor score, which suggests that the flavor of pomegranate juice cheese was pleasant and more acceptable for the panelists. 


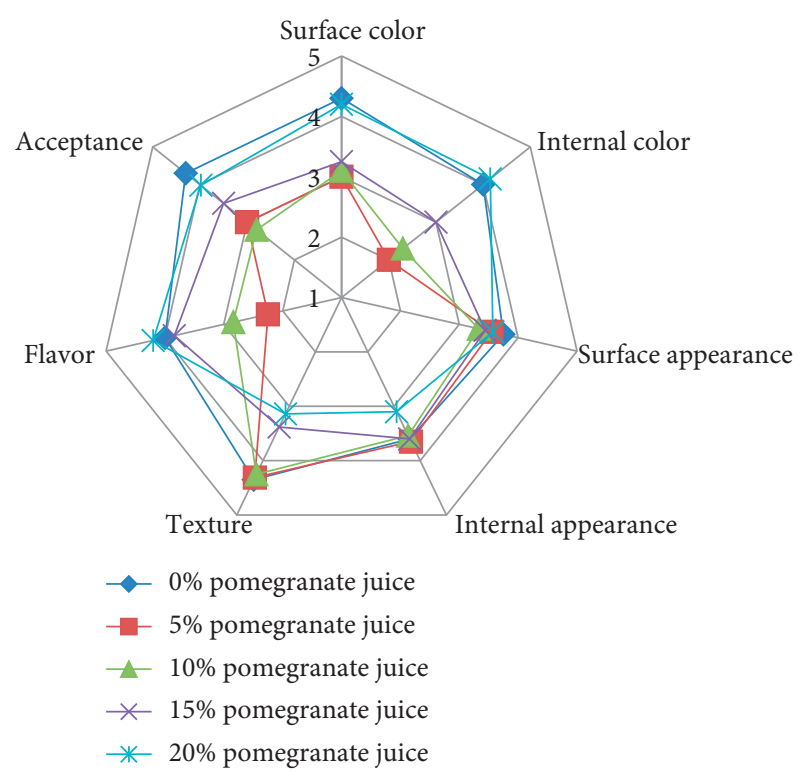

FIGURE 2: Sensory properties of Fruit whey-less Feta-type cheeses.

\section{Conclusion}

In order to produce whey-less cheese, MPC, WPC, and cream were mixed with fresh milk in different proportions, and optimization of its formula was developed by using Simplex-Lattice mixture design. The percentages of cream, MPC, and WPC at the optimal point were 45.6, 11.7, and $2.7 \%$, respectively. Addition of Pomegranate juice to the optimal whey-less Feta cheese changed its physicochemical and textural properties. This cheese has better antioxidant properties and oxidative stability, but its texture was weaker than the control. Further studies are necessary to improve the texture of the Fruit Feta-type cheese containing pomegranate juice (20\%). In general, it is recommended that cheese manufacturers produce fruit cheeses such as pomegranate cheese for people who are not interested in ordinary cheeses.

\section{Data Availability}

The data used to support the findings of this study are included within the article, and the raw data are available from the corresponding author upon reasonable request.

\section{Conflicts of Interest}

The authors declare that they have no conflicts of interest.

\section{References}

[1] A. Angelopoulou, V. Alexandraki, M. Georgalaki et al., "Production of probiotic feta cheese using propionibacterium freudenreichii subsp. shermanii as adjunct," International Dairy Journal, vol. 66, pp. 135-139, 2017.

[2] D. Bozoudi, S. Torriani, A. Zdragas, and E. LitopoulouTzanetaki, "Assessment of microbial diversity of the dominant microbiota in fresh and mature PDO feta cheese made at three mountainous areas of Greece," LWT - Food Science and Technology, vol. 72, pp. 525-533, 2016.

[3] S. L. Turgeon and L.-E. Rioux, "Food matrix impact on macronutrients nutritional properties," Food Hydrocolloids, vol. 25, no. 8, pp. 1915-1924, 2011.

[4] P. Meena and I. Raj, "Sensory evaluation and estimate the cost of production of guava based papaya fruit cheese," The Pharma Innovation, vol. 6, p. 254, 2017.

[5] H. Y. Choi, C. J. Yang, K. S. Choi, and I. Bae, "Characteristics of gouda cheese supplemented with fruit liquors," Journal of Animal Science and Technology, vol. 57, p. 15, 2015.

[6] A. S. Omer, T. O. Mohammed, and M. Abdeljabar, "Production of functional cheese from goat milk supplemented with baobab fruit pulp," Dissertation Honours Degree in Food Science and Technology, Sudan University of Science and Technology, Khartoum, Sudan, 2017.

[7] A. Mehto and P. K. Mehto, "Guava cheese preparation to reduce the perishable loss of fruits and influence of the chemical composition during storage of cheese," International Journal of Food Science and Nutrition, vol. 2, pp. 1-3, 2017.

[8] A. Zarban, M. Malekane, and M. R. Boghrati, "Antioxidant properties of pomegranate juice and its ability to neutralization of free radicals," Journal of Birjand University of Medical Sciences, vol. 14, no. 3, pp. 19-27, 2007.

[9] I. Kahramanoglu, "Trends in pomegranate sector:production, postharvest handling and marketing," International Journal of Agriculture, Forestry and Life Sciences, vol. 3, pp. 239-246, 2019.

[10] J. Han, M. Britten, D. St-Gelais et al., "Polyphenolic compounds as functional ingredients in cheese," Food Chemistry, vol. 124, no. 4, pp. 1589-1594, 2011.

[11] F. Salaün, B. Mietton, and F. Gaucheron, "Buffering capacity of dairy products," International Dairy Journal, vol. 15, no. 2, pp. 95-109, 2005.

[12] A. Gholamhosseinpour, M. Tehrani, S. Razavi, and H. Rashidi, "Evaluation and optimization of chemical and sensory properties of various formulations of recombined UF-Feta cheese analogues using response surface methodology," Iranian Food Science and Technology Research Journal, vol. 10, p. 2, 2014.

[13] H. Lashkari, M. J. Varid, M. H. Eskandari, and M. Varidi, "Optimization of whey less feta cheese production by usingmixture design," Journal of Food Science and Technology, vol. 74, pp. 283-298, 2018.

[14] AOAC, Official Methods of Analysis, Association of Official Analytical Chemists International, Maryland, DC, USA, 17th edition, 2000.

[15] J. Jiménez-Guzmán, A. Flores-Nájera, A. E. Cruz-Guerrero, and M. García-Garibay, "Use of an exopolysaccharide-producing strain of streptococcus thermophilus in the manufacture of Mexican panela cheese," LWT - Food Science and Technology, vol. 42, no. 9, pp. 1508-1512, 2009.

[16] S. M. H. Hosseini, H. Hashemi Gahruie, M. Razmjooie et al., "Effects of novel and conventional thermal treatments on the physicochemical properties of iron-loaded double emulsions," Food Chemistry, vol. 270, pp. 70-77, 2019.

[17] M. Nuñez, C. García-Aser, M. A. Rodríguez-Martin, M. Medina, and P. Gaya, "The effect of ripening and cooking temperatures on proteolysis and lipolysis in manchego cheese," Food Chemistry, vol. 21, no. 2, pp. 115-123, 1986.

[18] E. G. Bligh and W. J. Dyer, "A rapid method of total lipid extraction and purification," Canadian Journal of Biochemistry and Physiology, vol. 37, no. 8, pp. 911-917, 1959. 
[19] S. Kirk and R. Sawyer, Pearson's Composition and Analysis of Foods, Longman Group Ltd, Harlow, UK, 1991.

[20] H. M. Shahbaz, J.-J. Ahn, K. Akram, H.-Y. Kim, E.-J. Park, and J.-H. Kwon, "Chemical and sensory quality of fresh pomegranate fruits exposed to gamma radiation as quarantine treatment," Food Chemistry, vol. 145, pp. 312-318, 2014.

[21] M. Çam, Y. Hışıl, and G. Durmaz, "Classification of eight pomegranate juices based on antioxidant capacity measured by four methods," Food Chemistry, vol. 112, no. 3, pp. 721-726, 2009.

[22] S. Gunasekaran and M. M. Ak, Cheese Rheology and Texture, CRC Press, Boca Raton, FL, USA, 2002.

[23] M. Hashemi, F. Tabatabaei yazdi, M. Yavarmanesh, A. Milani, and A. Pasban, "Effect of rennet type, container and ripening time on microbial and physico-chemical properties of local Kurdish cheese," Iranian Journal of Food Science \& Technology, vol. 9, no. 37, pp. 135-147, 2013.

[24] Y. Buruk Sahin, E. Aktar Demirtaş, and N. Burnak, "Mixture design: a review of recent applications in the food industry," Pamukkale University Journal of Engineering Sciences, vol. 22, no. 4, pp. 297-304, 2016.

[25] V. Akbarpour, K. Hemmati, and M. Sharifani, "Physical and chemical properties of pomegranate (punica granatum l.) fruit in maturation stage," American-Eurasian Journal of Agricultural \& Environmental Sciences, vol. 6, no. 4, pp. 411-416, 2009.

[26] P. Putnik, Z. Kresoja, T. Bosiljkov et al., "Comparison the effects of thermal and non-thermal technologies on pomegranate juice quality: a review," Food Chemistry, vol. 279, pp. 150-161, 2018.

[27] E. Poyrazoglu, V. Gökmen, and N. Artık, "Organic acids and phenolic compounds in pomegranates (Punica granatum L.) grown in Turkey," Journal of Food Composition and Analysis, vol. 15, no. 5, pp. 567-575, 2002.

[28] A. A. Salwa, E. Galal, and A. E. Neimat, "Carrot yoghurt: sensory, chemical, microbiological properties and consumer acceptance," Pakistan Journal of Nutrition, vol. 3, pp. 322330, 2004.

[29] P. Walstra, T. J. Geurts, A. Noomen, A. Jellema, and M. A. J. S. van boekel, Dairy Technology, Principles of Milk Properties and Processe, Markel Dekker, New York, NY, USA, 1999.

[30] J. Hesari, M. R. Ehsani, A. Khosroshahi, and P. L. H. McSweeney, "Contribution of rennet and starter to proteolysis in Iranian UF white cheese," Le Lait, vol. 86, no. 4, pp. 291-302, 2006.

[31] M. I. Gil, F. A. Tomás-Barberán, B. Hess-Pierce, D. M. Holcroft, and A. A. Kader, "Antioxidant activity of pomegranate juice and its relationship with phenolic composition and processing," Journal of Agricultural and Food Chemistry, vol. 48, no. 10, pp. 4581-4589, 2000.

[32] L. Trigueros, M. Viuda-Martos, J. A. Perez-Alvarez, and E. Sendra, "Low fat yoghurt rich in pomegranate juice," Milchwissenschaft, vol. 67, pp. 177-180, 2012.

[33] A. Castañeda-Ovando, M. d. L. Pacheco-Hernández, M. E. Páez-Hernández, J. A. Rodríguez, and C. A. GalánVidal, "Chemical studies of anthocyanins: a review," Food Chemistry, vol. 113, no. 4, pp. 859-871, 2009.

[34] H. Lashkari, A. Khosrowshahi asl, and A. M. Madadlou, "Chemical composition and rheology of low-fat Iranian white cheese incorporated with guar gum and gum Arabic as fat replacers," Journal of Food Science and Technology, vol. 51, no. 10, pp. 2584-2591, 2014.
[35] B. Zisu and N. P. Shah, "Textural and functional changes in low-fat mozzarella cheeses in relation to proteolysis and microstructure as influenced by the use of fat replacers, preacidification and EPS starter," International Dairy Journal, vol. 15, no. 6-9, pp. 957-972, 2004.

[36] N. Shah, A. Pérez-Vicente, and C. García-Viguera, "Influence of storage temperature and ascorbic acid addition on pomegranate juice," Journal of the Science of Food and Agriculture, vol. 82, no. 2, pp. 217-221, 2002.

[37] M. Karaaslan, M. Ozden, H. Vardin, and H. Turkoglu, "Phenolic fortification of yogurt using grape and callus extracts," LWT - Food Science and Technology, vol. 44, no. 4, pp. 1065-1072, 2011.

[38] C. S. Ranadheera, C. Evans, M. Adams, and S. Baines, "Probiotic viability and physico-chemical and sensory properties of plain and stirred fruit yogurts made from goat's milk," Food Chemistry, vol. 135, pp. 1411-1418, 2012.

[39] B. Prieto, I. Franco, J. M. Fresno, J. G. Prieto, A. Bernardo, and J. Carballo, "Effect of ripening time and type of rennet (farmhouse rennet from kid or commercial calf) on proteolysis during the ripening of león cow milk cheese," Food Chemistry, vol. 85, no. 3, pp. 389-398, 2004. 